\title{
Business and government interdependence in emerging economies: \\ Insights from hotels in Ghana
}

\author{
Dr. Joseph Amankwah-Amoah* \\ Associate Professor (Reader) of international business \\ Kent Business School, University of Kent, \\ Sail and Colour loft, The Historic Dockyard, \\ Chatham, Kent ME4 4TE \\ TEL: +44 (0) 1634 (88)8870 \\ E-mail: J.Amankwah-Amoah@kent.ac.uk
}

\section{Professor Yaw A. Debrah}

Swansea University

School of Management

Singleton Park, Swansea, SA2 8PP

E-mail: y.a.debrah@swansea.ac.uk

Dr. Ben Q. Honyenuga

Interim Pro-Vice-Chancellor

Ho Technical University, Ho, Ghana

E-mail: bhonyenuga@htu.edu.gh

\author{
Ms. Paulina N. Adzoyi \\ Ho Technical University, \\ Department of Hospitality and Tourism Management \\ Ho Ghana \\ E-mail: padzoyi@htu.edu.gh
}

*Corresponding author 


\begin{abstract}
$\underline{\text { Abstract }}$
Although social science research is replete with scholarly works on capacity building, relatively few studies have focused on how government can induce capacity building among privately owned enterprises in emerging economies. We seek to fill the lacuna in our understanding by examining how a government can induce capacity building among privately owned enterprises. The study adopted a qualitative approach using semi-structured interviews with hotel owners, employees and managers, as well as government officials in Ghana to examine the issue. We identified three unique stages through which such capacity-building initiatives unfold encompassing diagnosing, renewal and customer centricity. The study revealed that capacity building through collaborative partnership was partly motivated by desire to overcome societal resistance to services seen as "tainted". The concluding section outlines a number of theoretical and practical implications.
\end{abstract}

\title{
Please cite as:
}

Amankwah-Amoah, J., Debrah, Y. A., Honyenuga, B. Q., \& Adzoyi, P. N. (2017). Business and government interdependence in emerging economies: Insights from hotels in Ghana. International Journal of Tourism Research , 1-31 


\section{$\underline{\text { Introduction }}$}

Over the past four decades, accelerated globalisation has been accompanied by the increasing contribution of services to the global economy (Jayaraman \& Luo, 2006; Vargo \& Lusch, 2004). In parallel, many governments have formulated and implemented industrial policies geared toward opening up their economies to capture the benefits of globalisation. In many developing countries, capacity building is one such policy (Farazmand, 2009; Tjosvold, Peng, Chen \& Su, 2008). In general, such policy is consistent with findings from prior studies which have highlighted the view that governments can play a role in firm-level capacity building (Cammett, 2007; Cull, Navajas, Nishida \& Zeiler, 2015; Farazmand, 2009; Ha \& Kang, 2015; Shao, Hernández \& Liu, 2015; Tjosvold et al., 2008). In many instances, governments in collaboration with companies, industries, customers and suppliers have engaged in capacity-building initiatives to create a sustainable business model (see also Suntikul \& Dorji, 2015).

Yet a closer look at the existing literature suggests that, despite some research on business and government interdependence and collaboration (Tian, Shi, Hafsi \& Tian, 2017; Tjosvold et al., 2008; Wong, Wei \& Tjosvold, 2015) and capacity development (e.g. Farazmand, 2009; Stephens et al., 2017; Victurine, 2000), our understanding of capacity building through collaborative partnership between government and business remains severely limited (see Shao et al., 2015). By capacity building through collaborative partnerships, we are referring to a situation where multiple stakeholders are mobilised and resources marshalled towards building firms' capabilities and fulfilling their role within the national economy.

Against this backdrop, the main purpose of this study is to examine how a government can induce capacity building among privately owned enterprises in an emerging economy. We focus on Ghana and the hotel industry for a number of reasons. Since the late 1950s, when Ghana gained independence, it has been touted as a "Beacon of Hope for Africa" and possesses attributes of good governance and the rule of law (GIPC, 2009). Ghana has also historically marketed itself as 
the "Gateway to Africa" (Amankwah-Amoah \& Debrah, 2010; Amankwah-Amoah \& Sarpong, 2016; Debrah, 2002) to attract foreign direct investment (FDI) and tourists, yet the hotel industry remains relatively underdeveloped and unable to cater for the needs of both international and domestic tourists and business travellers. The Ghanaian hotel industry lacks the capabilities of its counterparts in Southern Africa (e.g. South Africa) and East Africa (particularly Kenya). Therefore, focusing on this industry provides us with the opportunity to shed light on this issue and how the industry in a West African nation can be developed. In light of the limited prior scholarly works on the subject, we adopted a qualitative inductive research approach.

The study offers two main contributions to the existing literature. First, although some studies have suggested a need for a better understanding of business and government interdependence and collaboration (Tian et al., 2017; Tjosvold et al., 2008), our understanding of how the effects unfold over time remains unclear. We utilised insights from our evidence to develop a framework demonstrating how business and government interdependence and collaboration influence the initiation and implementation of capacity-building activities. Thus, our study deepens our understanding of the drivers and processes leading to capacity development. Second, we integrate perspectives from network theory (Granovetter, 1973; Samii, 2004) and literature on business and government interdependence (Tjosvold et al., 2008; Wong et al., 2015) to demonstrate how the process of capacity development is shaped by actions of other stakeholders. The study also enhances our understanding of business and government interdependence (Galbraith, 2011; Shah et al., 2006) by using capacity development in the hotel industry in Ghana to explicate the processes and pathways leading to a sustainable service business model.

The rest of the article is organised as follows. In the first section, a brief review of the literature on capacity building and network theory is provided. This is then followed by a discussion of the research context and approaches to data collection and analysis. Then, we outline the key findings, conclusions and implications of the study. 


\section{Capacity building and networks: a new perspective}

For analytical clarity, capacity building refers to "the process by which individuals, groups, organizations, institutions and countries develop their abilities, individually and collectively, to perform functions, solve problems and achieve objectives" (United Nations Development Programme (UNDP), 2007, p. 2). In a sense, it is the sum of efforts needed to nurture, enhance and utilise the skills of people and organisations to achieve objectives (UNDP, 1994, p. 2). To a large extent, capacity building involves the building and utilisation of the skills and actions of multiple stakeholders such as government, firms and local communities to help achieve a desired goal (Carlisle, Kunc, Jones \& Tiffin, 2013). Thus, it entails elements of business and government collaboration (Tjosvold et al., 2008; Wong et al., 2015). Such collaborations with governments, suppliers and customers can be utilised as a means of solving problems or overcoming constraints (Vargo \& Lusch, 2004). It can also be utilised to buttress knowledge between the focal firm, its suppliers, buyers and even rivals to facilitate the dissemination of best practices across organisational boundaries (Grant \& Baden-Fuller, 1995).

A growing body of literature suggests that successful capacity-building programmes entail cooperation and involvement of key stakeholders including customers, governments, suppliers and supply-chain partners (Airike, Rotter \& Mark-Herbert, 2016; Clarke \& MacDonald, 2016; Tu et al., 2006; Sheu, Yen \& Chae, 2006; Benton \& Maloni, 2005). It has been suggested that government actions are essential in inducing firms' capacity-building activities and the corresponding firm behaviour (Song, Dwyer, Li \& Cao; 2012). Governments seeking to build capacity in an underserved industry or sector can provide incentives and support to facilitate skills development, upgrade facilities and improve product safety (Amankwah-Amoah, 2014). Indeed, there is a role for governments in marshalling their resources and creating the enabling environment to facilitate collaboration between public- and private-sector institutions (Metcalfe \& Rees, 2005; Nwankwo, Phillips \& Tracey, 2007). Government-induced measures such as 
subsidies and investments can serve as catalysts for capacity building by firms to help improve their competitive position (Del Sol, 2002).

At another level, firm-level capacity building entails investments in training and development to equip employees to enhance their performance, and to deliver better organisational outcomes (Honadle, 1981; Lenz, 1980; World Bank, 2005). It has been suggested that some firms respond to competitive pressures arising from market competition by engaging in capacity-building initiatives to improve their value-adding activities, reduce costs, minimise waste and increase customer satisfaction (Metcalfe \& Rees, 2005; Wu \& Blackhurst, 2009). Such pressures also force firms to respond by deploying their existing resources and capabilities efficiently to counter the threat (Delmas \& Toffel, 2008). A significant insight emerging from the strategic operations management literature suggests that such capacity-building exercises enhance firms' supply-chain resilience and reduce vulnerabilities (see Wu \& Blackhurst, 2009).

Another relevant theoretical lens is network theory which contends that an organisation can enhance its competitiveness by developing and extending its external linkages or partners (Granovetter, 1973; Samii, 2004). To an extent, network theory pertains to how the interdependent partners and the position can provide opportunities for firms to engage in capacitybuilding exercises (Granovetter, 1973; Jean, Kim \& Sinkovics, 2012). Some studies have shown that external linkages or partners can help organisations to address some internal deficiencies by tapping into others' resources and expertise (Granovetter, 1973; Samii, 2004). Essentially firms in a network which are not limited by geographic proximity or lines of business are able to forge broader alliances with multiple government agencies and other firms to strengthen their expertise and resource base. In today's competitive environment, multi-partnership capacity-building initiatives are essential for success for firms operating in competitive service industries (UNDP, 1994). In a sense, firm-level capacity building involves making investments to improve facilities and processes to enrich customer experiences. 
The above line of reasoning implies that capacity building is a multi-stakeholder approach of strengthening firms' resources and capabilities in collaboration with government and other stakeholders, as shown in Figure 2. This framework demonstrates that the parties, actions, processes and pathways contribute towards developing a "customer centricity" model (Galbraith, 2011; Shah et al., 2006). The customer centricity "model" seeks to identify promising areas to create a competitive advantage by enhancing customer value and improving satisfaction level (Shah et al., 2006). It also focuses on putting the customers at the centre by discovering and responding to their requirements, needs, expectations and preferences (Shah et al., 2006). In spite of the extensive discussion of capacity building in the literature, the issue of multi-partnership capacity building to enhance firms' competitiveness has not been adequately explored. Accordingly, this study seeks to fill this gap in our understanding and enhance our perspectives on "firm-government" collaboration at an industry level to build competitive advantage and sustainable businesses. Based on the above analysis, we propose the following:

Proposition 1: Firms that take advantage of industry-building drive to distinguish and upgrade their services and offerings would benefit more from government-business capacity-building initiatives.

Proposition 2: Success of capacity-building initiatives in developing countries is more likely to be predicated on availability of quality human capital (i.e. skills, knowledge and abilities) than on facilities and services improvement.

\section{Insert Figure 1 about here}

\section{Research setting: The hotel industry in Ghana}

The research setting was the hotel industry in Ghana. Since gaining independence in the late 1950s, Ghana has gone through a number of socio-economic reforms (Amankwah-Amoah, 2016). At independence, the philosophy was that the government had to be involved in day-to-day 
business activities in many areas which were dominated by the private sector. As the private sector was controlled by "foreigners" (just as in many other post-colonial countries), it was perceived by the post-colonial government as exploitative of the "indigenous" poor and as such the sector could not be trusted to generate the economic growth needed to alleviate poverty (Vuerings \& Hanika, 1964). In line with this philosophy, the government established and operated multiple state-owned enterprises including hotels and guest houses across the country. The government controlled every sphere of the economy and applied a regimented system with respect to foreign exchange and this failed to promote private-sector investment. As was the case in many sub-Saharan countries in the immediate post-colonial period, the dominance of the socialist command economy had catastrophic economic consequences for Ghana. By the mid-1980s the Ghanaian economy was on its knees and badly needed rescued. The state hotels in Ghana had fallen into disrepair and could hardly attract any guests.

But at the same time, hotels in the private sector were severely underdeveloped resulting in a critical shortage of descent hotel accommodation in Ghana. This and other economic woes brought to an end the reliance on state enterprises as an economic development tool. The government of Ghana turned to the World Bank and the International Monetary Fund for assistance and this led to the launching of the Economic Recovery Programme (ERP) in the 1980s. This was an economic liberalisation and diversification programme to address the acute economic decline at the time. In 1983, the government, through the Divestiture Implementation Committee, offloaded its interest in state hotels such as the Continental Hotel (now Golden Tulip) in Accra, City Hotel in Kumasi, Golden Tulip in Kumasi and a host of government-owned hotelrelated facilities were sold to the private sector. The privatisation policy which was a strong aspect of the liberalisation process was seen as a catalyst which could transform the hotel sector (Akyeampong, 2009). At this point, the government effectively withdrew from operating hotels and focused its attention to creating a congenial atmosphere and environment in which the sector could flourish. For the first time in the country's history, multinational chain enterprises such as 
Novotel and Holiday Inn entered the sector with state-of-the-art technologies. The arrival of the MNCs gave impetus to the domestic firms to invest in the sector leading to the establishment of a number of luxury hotels across the country.

Today the sector can boast of local 4* hotels such as Fiesta Royal, African Regent Hotel, Cocoa Bean Hotel, etc. and multinational chains such as Movenpick and Kempinsky. As part of the economic reforms, the PNDC government passed PNDC Law 116 in 1985 to make tourism development a priority sector of the economy (Akyeampong, 2009; see also Asiedu \& Folmer, 2007). The reform's deliberate target of tourism had competitive effects on the industry, leading to some improvements in the services provided. This strategy began to bear fruits as there was an upsurge in business travellers staying in hotels in Ghana.

Since 2000, Ghana has marketed itself as a "Gateway" into the Economic Community of West African States' (ECOWAS) region for businesses and tourists (Debrah, 2002). In spite of these developments, the hotel industry in Ghana lags behind those of East African and Southern African countries in terms of competitiveness in prices and facilities/services offered and this has prompted the government in Ghana to undertake several initiatives aimed at enhancing the skills base and reputation of local hotels. In line with this objective, in 2003 the government created the Ministry of Tourism and Modernization of the Capital City, replacing the former Ministry of Tourism, to put tourism and capacity building of hotels, travel and hospitality-related firms and communities at the centre of the industry in Ghana. Former President J. A. Kufuor created the Ministry with the responsibility of improving tourism and hospitality facilities first in Accra and subsequently in all regions in the country. It focused special attention on the development of the capital city to showcase the country and help bring in potential investors. The establishment of the Ministry shifted the focus of the government to the promotion and development of the domestic (national) hotel industry (NDPC, 2005). 
Like many developing countries, Ghana has historically made investments and resource commitments to the service sector as a means of shifting the overdependence from mineral exploitation to a service economy (Amankwah-Amoah \& Debrah, 2016). The government initiatives also created opportunities for tourism to be a catalyst for economic development, employment creation and strengthening of the local infrastructure (NDPC, 2005). One pillar of the government policy was the promotion of collaboration among hotels to achieve economies of scale and improve their competitiveness. The new Ministry brought together the expertise of various agencies such as the Ghana Hoteliers Association (GHA), Hotel Catering and Tourism Institute (HCTI), Ghana Tourist Board (GTB) and Ghana Tourist Development Company (GTDC) to help unlock the potential of the industry. These agencies were assisted and supported by specialists from countries such as Morocco and Egypt to help with skill and capacity development (see GNA, 2005; NDPC, 2005). Historically, one of the major barriers to Ghana's ability to attract and develop the tourism sector has been the underdeveloped nature of infrastructure in the industry. By upgrading, up-skilling and up-equipping the sector, the government believed that it could make the national capital the gateway to the West African region and Africa as a whole. Hence, the government embarked on FDI promotion aimed at attracting investors to the industry, particularly in the building of new hotels.

\section{Methodology and research design}

Given the limited knowledge of firm-level capacity building through collaborative partnership with the government, a qualitative inductive research approach was considered most appropriate for this study (Birkinshaw, Brannen \& Tung, 2011; Riley \& Love, 2000). To identify informants, we utilised a variety of approaches encompassing the direct approach, networking and snowballing approach (direct referrals), which are highly recommended when exploring such issues (see Acquaah, 2007; Biernacki \& Waldorf, 1981; Noy, 2008). Indeed, snowball sampling has been found to be particularly effective in deriving knowledge that is dynamic and informative 
(Biernacki \& Waldorf, 1981; Noy, 2008). In line with this approach and with the view of attaining flexibility and an opportunity to explore the intricacies in the interdependent/collaborative relationship (Bryman \& Bell, 2011), a semi-structured interview with relevant stakeholders in the hotel industry was used to gather evidence. In line with the approach, a purposive sampling approach was adopted to interview a population of stakeholders in the hotel industry in Ghana. First, the researchers initially contacted officials of the Ministry of Tourism, GHA and the GTB to help identify key informants, arrange and conduct the interviews. In line with Kvale's (2007) suggestion, an interview guide was developed and piloted among some owners and line managers in the hotel industry to elicit their views on the clarity of the questions.

After this, the real data/evidence gathering/interviews stage commenced. From the outset, permission was sought from the individuals and their employers/organisations before the interviews took place. Those interviewed included owners, employees and managers of the hotels, as well as officials of the Ministry of Tourism, GTB, GHA, the Ghana Revenue Authority and private firms that have arrangements with hotels for serving their clients/customers and employees. At the same time the researchers used their connections and networks to identify other key informants. This was necessary to avoid bias and achieve a balanced view. In all, interview data were gathered from government officials, other staff, owners and stakeholders with diverse views on the capacity, potential and prospects of the industry. Our study is not only predicated on semi-structured interviews but also encompasses observations and archival data.

The hotel employees and owners were asked about channel relationships and co-operation with customers and suppliers, environmental activities and initiatives to reduce waste. They were also asked about their supply chain partners and collaborations. The informants were also interviewed to elicit information about the effects of the institutional and external factors on the businesses and the industry. All the informants were asked about the main challenges facing the industry, constraints and recent initiatives on capacity development. It is worth noting that although many 
of the owners initially focused on just running the hotel after founding, in recent years they have gravitated toward becoming hospitality firms encompassing hotel, restaurant and night clubs.

\section{Insert Table 1 about here}

Table 1 provides background information on the informants. The fieldwork data gathering took place in Southern Ghana mainly along the coast where tourism is vibrant and there are more hotels catering to the needs of both local and foreign customers/clients. In addition to the interviews, secondary sources such as press releases, newsletters, newspaper reports, trade magazines and company brochures were collected from the organisations and individuals to aid the analysis. In particular, official publications of the Ministry of Tourism, the Ghana Tourism Board and the World Tourism Organization were also obtained and analysed. Over a three-month period, we conducted extensive reviews of such archival data to inform our analysis. The data collection took place between June and December 2012 and each interview lasted between 30 and 90 minutes. All the interviews yielded significant field notes which were handwritten. The interview data were transcribed no later than one hour after an interview. We then organised the interview data along key themes such as current developments including the business and environmental conditions, challenges and opportunities in the industry. Multiple follow-up phonecalls were made to some interviewees in January and June 2013 to clarify issues and resolve ambiguities regarding the interview data. In all, 122 interviews were conducted.

Regarding archival data, we collected newsletters, newspaper cuttings, annual reports, photographs, web postings, hard copies of past advertisements and promotional posters. Some of the owners also provided data on their performance and number of customers. We analysed these data also by coding and organising them along key themes of current development, challenges and opportunities. Data collected were analysed using the three content-analysis procedures advocated by Miles and Huberman (1994) and Eisenhardt (1989), namely: data reduction, data 
display, and drawing and verifying conclusions. We then compared and contrasted our key themes from the hotel owners, managers, employees and government officials. We also attempted to chart how these capacity developments evolved by organising the data into categories such as early stage, short-medium term and late stage. We utilised the interview transcripts, field notes and archival data to identify the common themes.

\section{Findings and analysis}

Capacity building is essential for firms to develop expertise to become competitive as well as respond to the evolving competitive environment. An analysis of the findings revealed that hotel owners have responded to the challenges and opportunities arising from the collaboration between the government and the private sector by initiating activities aimed at improving the ability of hotels to attract, meet and satisfy customers' requirements. These responses are discussed in terms of the phases of service evolution. Table 2 provides a summary of the key shifts in the evolution of the industry.

\section{Insert Table 2 about here}

\section{Phase 1: Identifying capacity constraints}

The analysis of the evidence gathered suggests that the ability to pursue successful capacity development activities requires environmental scanning to identify the root causes. This phase reflects the evolution and early stage of development. It focused on identifying the constraints and barriers to the development of the industry. A major constraint facing the industry in the pre-ERP period was that most of the firms had started as unranked hotels but some had infrastructure and facilities capable of upgrading to first class hotels. This was the case of the state hotels but private hotels that existed at the time were few in number, and the standards and quality were poor. For years, the Ghanaian hotel industry had struggled to shake off its reputation for poor services and 
hence its inability to attract customers. The informants asserted that by the end of the 1980s the collaborative efforts between the government and the hotels had begun to bear fruits in terms of raising standards across the industry, restoring the battered image of the industry and enhancing the capacity of local firms to attract travellers. The informants also pointed out that while the collaborative efforts had begun to address the problems on the supply side, the industry faced demand-side problems. These included traditional beliefs, customs, attitudes and perceptions of hotels as places for meeting prostitutes and for unsavoury activities. Thus, social issues such as negative attitudes towards hotels and the consequent consumers' resistance remained as obstacles to the industry's development. During an interview, one hotelier (who has been in the hotel business for over 50 years) concurred that:

"For a long time in the history of Ghana, hotels were viewed as a place for prostitutes and irresponsible people who left their homes to indulge in all kinds of vices. It tarnished our image and what we do. So in some Ghanaian languages such as Ewe prostitutes are today referred to as 'hotelitorwo' meaning people who stay in hotels."

While in recent years these negative attitudes, stereotypes and perceptions are on the decline, they still remain a significant barrier in the attraction of customers in the industry. On this issue, another owner also noted:

"Our reputation as an industry is changing but when I started even some family members thought I was assisting the devil by providing a location for his activities to take place ... family members did not even believe I could succeed. So we have come a long way in our efforts to shake off the negative image."

Another constraint was the nature of customers. One official of the Ministry of Tourism noted:

"In Ghana, unlike in industrialised countries (developed world) where people consciously plan and embark on holidays at least once a year to other parts of the country and stay in 
hotels, most Ghanaians would normally spend their annual leave holidays in their villages/towns where a warm welcome awaits them in their family houses."

The informants hence contend that they face more social-cultural problems in the hotel industry and that the government and private-sector collaboration initiatives should focus on addressing them. This is necessary to address the demand side of problems in attracting customers. Thus without enough customers, improvements in facilities and capabilities of employees would not matter much.

\section{Phase 2: Industrial renewal and upgrading}

During this stage, a range of activities occurred aimed at renewing and upgrading the expertise and capabilities of firms within the industry to help improve their competitiveness. In some cases, the initiatives unfolded as a result of government or firm-level actions. It was uncovered that a range of activities including reputation building in the local communities had been undertaken which were aimed at helping the industry to shed its poor image on service provision, quality of facilities and safety. One of the strategies adopted by the service firms - community engagement to attract new customers - was precipitated by the capacity-building initiatives. The informants emphasised that building a diverse customer base through community-based promotions and engagements has helped to equip the industry and firms to improve their long-term survival and overcome the traditional negative image of the industry. It was further asserted that some of the owners have engaged in community programmes such as fun-fairs and sports events to help overcome societal reluctance to stay in hotels or use hotel services. As a hotel owner in Accra noted:

"I see what we are doing in community involvement and initiatives as a way of 'branding' the industry to uplift our image in society and to stand out as an industry." 
It was reported that a number of workshops and training programmes were organised by the government and hotel-related associations to sensitise the hotel industry to deliver to the required standards. As part of the Ghanaian government's determination to develop the hotels and tourism sector, it bid for and won the African Cup of Nations football (soccer) tournament (CAN 2008). It was held in Ghana from 20th January to 10th February 2008. To host the soccer events the government provided assistance to hotels to improve their capacity to accommodate the visitors to the games. In order to meet the standards and repair their reputations, hotel owners/managers borrowed to improve upon their facilities and in some cases to expand them so as to be able to host visitors to Ghana for sports and other social events. As one owner noted:

"We had to use all our cash reserves for promotions and ... for providing new facilities to prepare us for the CAN 2008 sports competition."

The sports events provided an opportunity to highlight some of the challenges in the industry and also forced the government to act, in the form of improving transport facilities to hotels and training of people in the sector. These provided the much needed capital injection into the industry to generate some kind of revitalisation of tourism by drawing in more visitors. On this issue, a hotel owner in Accra noted:

"The competition injected fresh money into our industry [to improve facilities and standards], but more needs to be done to attract visitors to come here and use our hotels."

Thus, CAN-2008 provided the opportunity to upgrade and build the capacity of hotels to help overcome consumer resistance and reluctance to the use hotel services. In this regard, the quotation below from a government official outlined the issue:

"With respect to Can 2008, we are convinced we did the right thing because it afforded the opportunity to the hotels to improve upon their facilities and that has long-term implications for them. In addition before you recommend which hotels to host players and 
officials you need to give a fair playing ground to all of them to improve their facilities and after inspection you recommend the quality ones. The hotels that were fortunate to be officially nominated to host the players and officials can testify to the fact that it was worth the investment."

As part of scaling up and retooling of the industry, many of the owners and operators have invested in new services such as hotel-wide wi-fi connections, entertainment and health facilities. This is part of a strategy to help attract new and fast-growing youth customers visiting the country. As an owner noted:

"To get the young people here the access to internet is as important as beds and towels to them."

As one hotel owner put it:

"We cannot go on like this. We have to broaden our services to bring in new customers for the business and I mean locals."

Another owner in Greater Accra adds:

"There is a rising middle class that wants to have freedom to be on their own rather than staying with family and friends when they travel to the cities and urban centres as was the case in times past. They normally constitute the walk-in guest at our facilities."

These steps have enabled the forward-looking hotels to tap into the changing lifestyle and people's attitudes towards hotels in the country. These have helped them to attract some new customers, thereby reducing their over-reliance on a few locals and foreign tourists. Consequently, some of the firms have started targeting the growing middle class with high disposable income using these new services and facilities as unique selling points. As a manager of a hotel in Accra commented: 
"We now provide all kinds of packages to people who have weddings and funerals to come to the hotels instead of doing those activities in their homes."

Another dimension of the initiatives by the industry emphasised the need for capacity building to go beyond mainly the involvement of government agencies and hotels to include other stakeholders. Previous attempts by the government and industry associations to engage in capacity building emphasised seminars and workshops but these were not linked to policy framework to create a friendly regulatory environment in which the industry could flourish. On skills development, the capacity-building initiatives supported by the government included short courses, seminars and attachment programmes in educational institutions such as universities and colleges in Ghana to provide the joined-up thinking needed to prepare the industry for competition to attract inter- and intra-African tourists. These programmes brought together these stakeholders to help address the skills deficiencies of the industry.

More importantly, the programmes provided the hotels with access to their peers from the newly emerging market economies in Asia and Europe. The Government brought in well-established hotel owners to share their experiences with the local firms. The study also uncovered that firms that adopted and participated in the capacity-improvement programmes also experienced indirect benefits such as enhanced reputation for reliable and quality services as well as increased customer satisfaction. The fieldwork also revealed that another driver for change was the clients of the businesses including government institutions and companies. Many high-profile visitors to Ghana tend to be guests of the government, multilateral institutions and multinational companies with capacity to pay for the luxury facilities that the 4-5 star hotels offer. These institutions and companies usually hold their conferences and training programmes in the hotels. It is therefore not surprising that almost all the hotels in Ghana strive to provide conference facilities to enable them take advantage of the market. As such, one hotel customer noted on a visit to a hotel: 
"So many things have changed since my last visit. The atmosphere is different and better.

The amenities have improved. They now even have recycling bins and donation boxes to local charities."

Taken together, the data indicate two dimensions of capacity building: community-based and skills-based (see Figure 2). The community-based capacity building emphasises the integration of firm-level resources, networks of relationships, leadership and support of local stakeholders such as government institutions and local communities in solving the problems in the hotel industry. One aspect of the community-based capacity building revolved around the improvement of safety issues in the industry. The skills-based capacity-building activities focus on training and development to upgrade the expertise of employees.

\section{Phase 3: Market development and customer focus}

Following the integrated capacity-building approach to improve facilities of hotels and raise awareness, the firms have also sought to bring in expertise to help improve the range of services provided, thereby attracting more travellers and vacationers. The analysis of the fieldwork evidence revealed that the skills development remains central in achieving higher customer satisfaction. In this respect, the informants noted firms' attempts towards hiring individuals with expertise across functional areas such as marketing, accounting and food safety to deliver improved customer experiences. It was acknowledged that whilst the majority of the people with these requisite skills receive their training via the polytechnics and vocational/technical schools, a few, especially the managerial staff, attend higher institutions such as universities. It was also stressed that one of the reasons for limited competitiveness of many hotels has been a lack of skilled individuals to fill key positions and the quotation below attests to this:

"We have thousands of applicants who lack the critical skills required. Some of the young graduates from the polytechnics and universities always want to be managers instead of 
applying the skills they have learnt at the operational level. How many managers can I employ at a time?"

Similarly, an owner notes:

"I would rather prefer to recruit the skilled (trained) people and give them further training over the years to master their occupations and then to progress to a managerial path."

A senior manager at one of the hotels commented that:

"At my previous role in government, I was responsible for the co-ordination and development of the hotel industry... when I arrived in the hotel, I realised that neither the government nor the industry had addressed the critical issue of skills shortages."

The non-professional employees who work as security and waiters are usually recruited from the pool of unemployed school leavers. These categories of employees often use the hotel work as a springboard to other jobs and therefore lack commitment in delivering for the customer. Due to the high labour turnover rate in the industry, there is a reluctance to train employees for fear of losing them. Therefore, the capacity-building activities entail addressing this problem by providing training to all categories of staff and thereby encouraging employee retention and commitment to the industry and moving towards a model focusing on the provision of excellent customer service. The informants testified that the capacity development programmes are equipping staff towards a "customer centricity" culture.

\section{Insert Table 3 about here}

Table 3 summarises some the outcomes of the capacity-building initiative. By the end of this phase, the firms had extended their value-chain activities to include skill formation, recycling waste and multi-partner distribution channels to improve their competitiveness. Based on the 
above, we articulate the three phases in key developments and evolution of the industry that have occurred towards achieving a sustainable service business model (see Figure 2).

\section{Insert Figure 2 about here}

\section{Discussion and conclusion}

In this paper we set out to examine how governments can induce capacity building among privately owned enterprises. Using insights from the hotel industry in an emerging economy, we uncovered three key stages, namely identifying capacity constraints, industrial renewal and upgrading, and market development and customer focus. These stages demonstrate that the awareness programmes initiated by the government have alerted the organisations to some of the internal weaknesses such as poor facilities and the need to upgrade. We also shed light on the role of multi-stakeholders in capacity development. These efforts have resulted in skills and facilities upgrading which have helped to change locals' perceptions of hotels and to shift consumers' attitudes. It can be argued that these changes have led to improvements in facilities and the revitalisation of the industry to fulfil its full potential.

In spite of these developments, the hotel industry faces additional challenges, notable amongst them are lack of skilled personnel/professionals, multiplicity of taxes, low patronage from domestic vacationers and rising operating costs. The development of capacity entails investments in resources and human capital, which is often beyond the scope and financial muscle of small firms. The cost associated with such capacity building in such a developing economy is likely to have negative repercussion for such firms and threaten their survival.

\section{Implications for practice and research}

From a theoretical standpoint, the study contributes to research on capability development. First, in light of increasing interest in capacity building and desire of many nations to improve the 
competiveness of local firms, this study contributes to the literature by explaining how such capacity-building attempts are manifest. We have contributed to the literature by delineating how institutional and social pressures interact with firm-level factors in determining the nature and pace of capacity-building initiatives. These shed light on network theory (Granovetter, 1973; Borgatti \& Foster, 2003) by emphasising the role played by the hotels and government agencies. Although there is a considerable body of literature on the role of government in capacity building, particularly training, to boost the skills base (e.g. Lin \& Wong, 2013), the question of how firms respond and engage in capacity building in the face of looming competitive challenges has not been adequately addressed (Witt \& Lewin, 2007). Although past studies have examined firmlevel capacity building, little attention has been devoted to capacity building through collaborative partnership. Thus, we have filled this void in the literature using insights from Ghana to articulate how business and government interdependence can impact on firm competitiveness and ability to respond to the changing business environment.

From a practical standpoint, the study draws attention to the pertinent issues facing the development of the industry. The analysis suggests that the ability to unlock the potential of hotels through skills development and strong relationships through social engagements can help to ensure a firm's long-term survival. For local firms, there is a need to establish structures and processes for external knowledge acquisition either foreign or local, to allow the inflow of new knowledge to help enhance their competitiveness. Besides deploying resources and strengthening government agencies in identifying the shortcomings of local businesses, there is also a need for local firms to take charge of their own destiny. In this direction, there is a need for wider government supports and incentives to encourage firms to enhance their capacity.

However, there are some limitations of the study. First of all, it focused on a single industry with its unique features. Therefore, future research should seek to obtain a larger and cross-industry sample. There is a possibility that our sample failed to capture other hotel owners, employees and 
managers whose experiences and interactions with government might differ significantly from those presented here. It is also possible that a different set of government officials might have different perspectives of the issues. Indeed, given the strong political divide in Ghana, it might be that different political party officials in government might present a different picture in terms of business-government relationships. Given these shortcomings, it might be useful for these findings not to be generalised to other industries or sectors.

A natural extension of this study would be to examine the issue across multiple industries to help assess the generalisability of the findings. Another avenue for future research would be to examine how such capacity-building exercises can harm organisational resiliency and vulnerability. It would be interesting to examine whether government-induced capacity-building initiatives have the potential to lead to complacency and inefficiency in the value chain of the focal firm. Future research could also examine collaborations between the third-sector and private firms towards capacity building. In closing, we hope that this study turns out to be a wake-up call to governments and companies about the need to create a sustainable service delivery model through collaborative partnership.

\section{References}

Acquaah M. 2007. Managerial social capital, strategic orientation, and organizational performance in an emerging economy. Strategic Management Journal, 28: 1235-1255.

Airike PE, Rotter J P, Mark-Herbert, C. 2016. Corporate motives for multi-stakeholder collaboration-corporate social responsibility in the electronics supply chains. Journal of Cleaner Production 131: 639-648.

Akyeampong O. 2009. Structural adjustment programme and the tourism development in Ghana 1985-2005. Ghana Social Science Journal 5(6): 1-26.

Amankwah-Amoah J. 2014. Organizational expansion to underserved markets: Insights from African firms. Thunderbird International Business Review 56(4): 317-330.

Amankwah-Amoah J. 2016. The evolution of science, technology and innovation policies: A review of the Ghanaian experience. Technological Forecasting and Social Change 110: 134-142. 
Amankwah-Amoah J, Debrah, YA. 2010. The protracted collapse of Ghana Airways: lessons in organizational failure. Group \& Organization Management 35: 636-665.

Amankwah-Amoah J, Debrah, YA. 2016. Toward a construct of liability of origin. Industrial and Corporate Change, 1-23.

Amankwah-Amoah J, Sarpong D. 2016. Historical pathways to a green economy: The evolution and scaling-up of solar PV in Ghana, 1980-2010. Technological Forecasting and Social Change 102: 90-101.

Asiedu KF, Folmer H. 2007. Does privatization improve job satisfaction? The case of Ghana. World Development 35(10): 1779-1795.

Benton WC, Maloni M. 2005. The influence of power driven buyer/seller relationships on supply chain satisfaction. Journal of Operations Management 23(1): 1-22.

Biernacki P, Waldorf D. 1981. Snowball sampling: Problems and techniques of chain referral sampling. Sociological Methods \& Research, 10(2), 141-163.

Birkinshaw J, Brannen MY, Tung RL. 2011. From a distance and generalizable to up close and grounded: reclaiming a place for qualitative methods in international business research. Journal of International Business Studies 42(5): 573-581.

Borgatti SP., Foster PC. 2003. The network paradigm in organizational research: A review and typology. Journal of Management, 29(6): 991-1013.

Bryman A, Bell E. 2011. Business research methods. 3rd Edition, Oxford: Oxford University Press.

Cammett M. 2007. Business-government relations and industrial change: The politics of upgrading in Morocco and Tunisia. World Development 35(11): 1889-1903.

Carlisle S, Kunc, M, Jones E, Tiffin S. 2013. Supporting innovation for tourism development through multi-stakeholder approaches: experiences from Africa. Tourism Management 35: $59-69$.

Clarke A, MacDonald A. 2016. Outcomes to partners in multi-stakeholder cross-sector partnerships: A resource-based view. Business \& Society,1-35.

Cull R, Navajas S, Nishida I, Zeiler R. 2015. A new index of the business environment for microfinance. World Development 70: 357-388.

Debrah, Y.A. (2002) Doing Business in Ghana. Thunderbird International Business Review 44(4): 495-513.

Del Sol P. 2002. Responses to electricity liberalization: The regional strategy of a Chilean generator. Energy Policy 30(5): 437-446.

Delmas MA, Toffel MW. 2008. Organizational responses to environmental demands: Opening the Black Box. Strategic Management Journal 29: 1027-1055. 
Eisenhardt KM. 1989. Building theories from case study research. Academy of Management Review 14: 532-550.

Galbraith JR. 2005. Designing the customer centric organization: a guide to strategy structure and process. Jossey-Bass: San Francisco.

Ghana Tourist Board Statistical Fact Sheet. 2009. Statistical fact sheet. GTB: Accra.

GNA, 2005. Ghana Earns $\$ 800 \mathrm{~m}$ From Tourism. 26 May. Retrieved from http://www.ghanaweb.com/GhanaHomePage/NewsArchive/artikel.php?ID=82361.

Granovetter MS. 1973. The strength of weak ties. American Journal of Sociology 78(6): 13601380.

Grant RM, Baden-Fuller C. 1995. A knowledge-based theory of inter-firm collaboration. Academy of Management Journal 1: 17-21.

Ha E, Kang MK. 2015. Government policy responses to financial crises: identifying patterns and policy origins in developing countries. World Development 68: 264-281.

Honadle BW. 1981. A capacity-building frame-work: a search for concept and purpose. Public Administration Review 41(5): 575-580.

Jayaraman V, Luo Y. 2006. Creating competitive advantages through new value creation: a reverse logistics perspective. Academy of Management Perspectives 20(1): 56-73.

Jean R-J. Kim, BD, Sinkovics R. 2012. Drivers and performance outcomes of supplier innovation generation in customer-supplier relationships: The role of power-dependence. Decision Sciences 43(6): 1003-38.

Kvale S. 2007. Doing interviews. Thousand Oaks: Sage.

Lenz RT. 1980. Strategic capability: a concept and framework for analysis. Academy of Management Review 5(2): 225-234.

Lin C, Wong SM. 2013. Government intervention and firm investment: evidence from international micro-data. Journal of International Money and Finance 32: 637-653.

Metcalfe B, Rees C. 2005. Theorizing advances in international HRD. Human Resource Development International 8(4): 449-465.

Miles MB, Huberman AM. 1994. Qualitative data analysis (2nd ed). Sage: Beverly Hills, CA.

Nankervis AR, Debrah Y, 1995. Human resource management in hotels: a comparative study. Tourism Management 16(7): 507-513.

NDPC (National Development Planning Commission), 2005. Growth and Poverty Reduction Strategy (GPRS II). Accra: NDPC.

Noy, C. 2008. Sampling knowledge: The hermeneutics of snowball sampling in qualitative research. International Journal of Social Research Methodology, 11: 327-344 
Nwankwo E, Phillips N, Tracey P. 2007. Social investment through community enterprise: the case of multinational corporations involvement in the development of Nigerian water resources. Journal of Business Ethics 73: 91-101.

Riley RW, Love L. 2000. The state of qualitative tourism research. Annals of Tourism Research 27: $164-187$.

Samii M, 2004. Globalization and IT. In: Samii, M., Karush, G. (Eds.), International Business and Information Technology. Routledge, New York.

Shah D, Rust RT, Parasuraman A, Staelin R, Day, GS. 2006. The path to customer-centricity. Journal of Service Research 9(2): 113-124.

Shao Y, Hernández R, Liu P. 2015. Government intervention and corporate policies: Evidence from China. Journal of Business Research 68(6): 1205-1215.

Sheu C, Yen HR, Chae B. 2006. Determinants of supplier-retailer collaboration: evidence from an international study. International Journal of Operations \& Production Management 26(1): $24-49$.

Song H, Dwyer L, Li G, Cao Z. 2012. Tourism economics research: a review and assessment. Annals of Tourism Research 39(3): 1653-1682.

Stephens T, De Silva AP, Beane, A ...Abeynayaka, A. 2017. Capacity building for critical care training delivery: Development and evaluation of the Network for Improving Critical Care Skills Training (NICST) programme in Sri Lanka. Intensive and Critical Care Nursing, 39: 28-36.

Suntikul W, Dorji U. 2015. Tourism development: the challenges of achieving sustainable livelihoods in Bhutan's remote reaches. International Journal of Tourism Research, 1-11.

The Economist. 2004. Do it yourself: The self-service economy. 372(8393): 16.

Tian Z, Shi J, Hafsi T, Tian B. 2017. How to get evidence? The role of government-business interaction in evidence-based policy-making for the development of Internet of Things industry in China. Policy Studies, 38(1): 1-20.

Tjosvold, D, Peng, AC, Chen YF, Su, F. 2008. Business and government interdependence in China: Cooperative goals to develop business and industry. Asia Pacific Journal of Management, 25(2): 225-249.

Tu Q, Vonderembse MA, Ragu-Nathan TS, Sharkey TW. 2006. Absorptive capacity: enhancing the assimilation of time-based manufacturing practices. Journal of Operations Management 24: 692-710.

United Nations Development Programme (UNDP). 1994. Annual report for 1993. United Nations: New York.

United Nations Development Programme (UNDP). 2007. Capacity development and public private partnerships. United Nations: New York. 
Vargo SL, Lusch RF, 2004. Evolving to a new dominant logic for marketing. Journal of Marketing 68(1): 1-17.

Victurine R, 2000. Building tourism excellence at the community level: capacity building for community-based entrepreneurs in Uganda. Journal of Travel Research 38(3): 221-229.

Vuerings R, Hanika FDP. 1964. Problems of industrial management in developing countries: the re-adjustment of private firms in independent Black Africa. Management International 4: $105-115$.

Witt MA, Lewin AY. 2007. Outward foreign direct investment as escape response to home country institutional constraints. Journal of International Business Studies 38(4): 579594.

Wong A, Wei L, Tjosvold D. 2015. Business confidence in government regulators: cooperative goals and confirmation of face in China. International Journal of Conflict Management 26(3): 268-287.

World Bank. 2005. Capacity building in Africa. World Bank Operations Evaluation Department: Washington, DC.

$\mathrm{Wu}$ T, Blackhurst J. (eds.), 2009. Managing supply chain risk and vulnerability: tools and methods for supply chain decision makers. Springer: New York.

Yin RK. 1994. Case study research: Design and methods. Second 2nd edition, Sage Publications: Beverly. 
Figure 1: An integrated model of capacity building

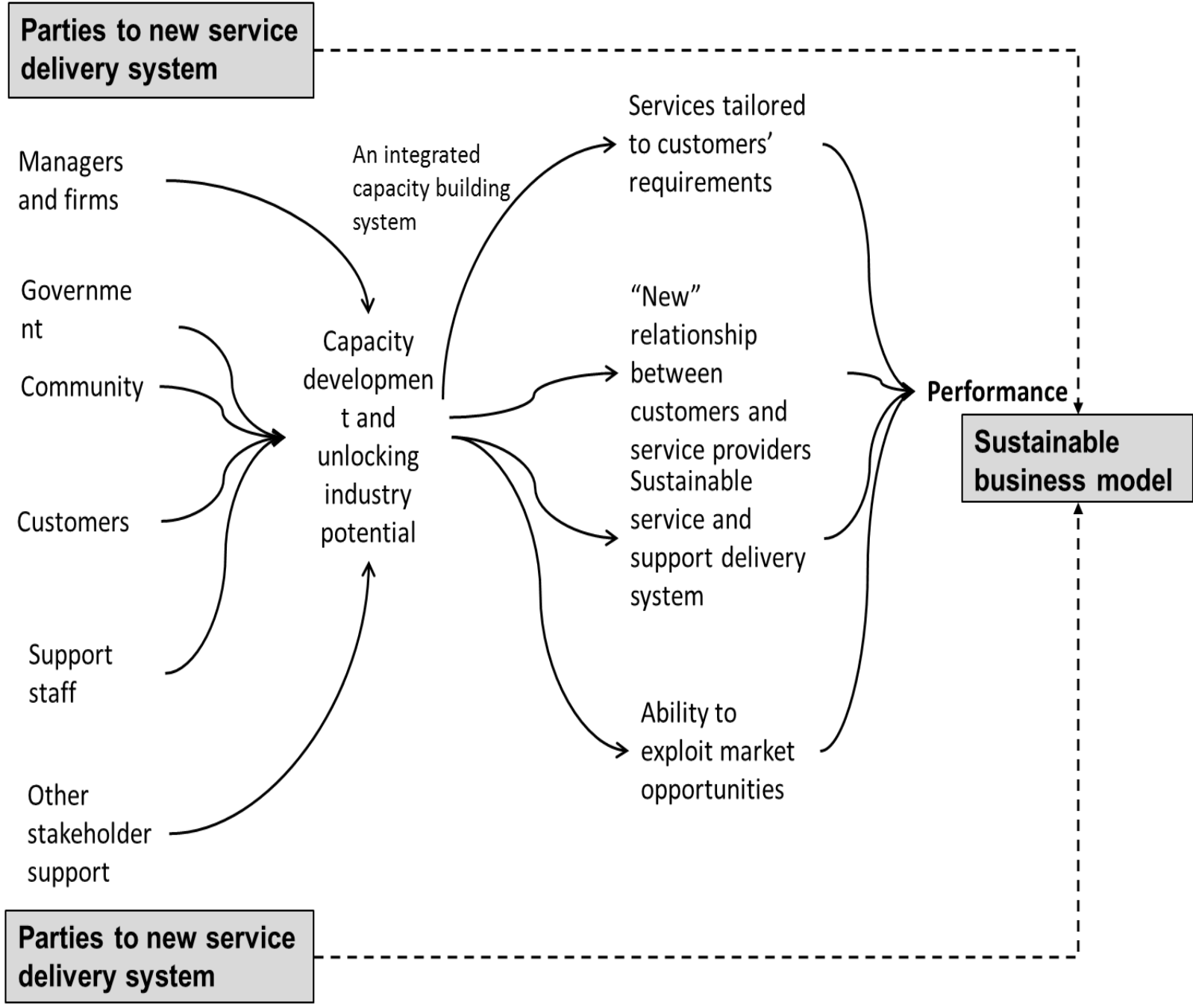




\section{Figure 2: Phases in the capacity development}

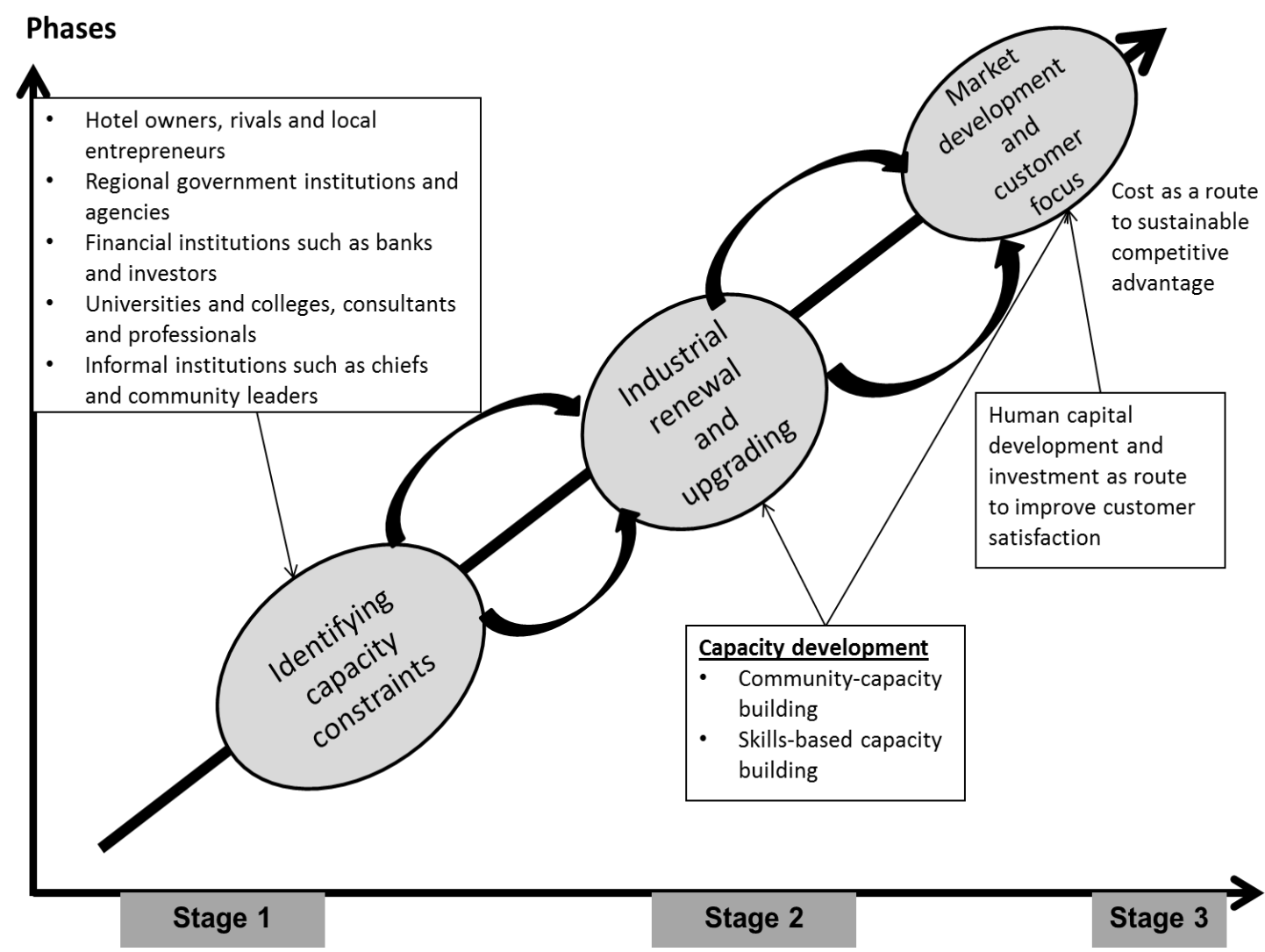

\section{Table 1: List of informants}

\begin{tabular}{|l|l|}
\hline Informants & Number \\
\hline Owners/managers of hotels & 35 \\
\hline Senior employees of the hotels & 55 \\
\hline Executives of the Ghana Hotels Association & 8 \\
\hline Senior government officials including junior minister, policy- & 24 \\
makers and senior civil servants and also hotel users (firms & \\
\hline That conduct workshops and training in hotels) & $\mathbf{1 2 2}$ \\
\hline
\end{tabular}




\section{Table 2: Factors in the evolution of the industry}

\begin{tabular}{|c|c|c|}
\hline Features & Problems prior to capacity development & Nature of the environment after initial capacity building \\
\hline $\begin{array}{l}\text { Institutional } \\
\text { infrastructure } \\
\text { and } \\
\text { dynamics }\end{array}$ & $\begin{array}{l}\text { - Limited or no government support for } \\
\text { infrastructure development. } \\
\text { - Outdated and inefficient service } \\
\text { delivery system. } \\
\text { - Lack of competitiveness of local } \\
\text { hotels relative to regional rivals. } \\
\text { - Lack of awareness of the plight of the } \\
\text { industry. }\end{array}$ & $\begin{array}{l}\text { - Government-backed loans and direct support in developing the capacities } \\
\text { of local hotels. } \\
\text { - Hotels became increasingly aware of the opportunities inherent in the } \\
\text { business environment through government/private-sector initiatives. } \\
\text { - Hotels became equipped with up-to-date technologies in managing } \\
\text { bookings and attracting customers. } \\
\text { - Improved internet and other facilities for customers. } \\
\text { - Incentives for firms to upgrade facilities to improve customer experience. } \\
\text { - Marshalling government support and firms' resources to improve service } \\
\text { delivery. } \\
\text { - Government initiatives to prepare organisations to manage and handle } \\
\text { future capacity issues such as hosting of international conferences and } \\
\text { sports events. }\end{array}$ \\
\hline $\begin{array}{l}\text { Local } \\
\text { traditions }\end{array}$ & $\begin{array}{l}\text { - Perceptions of hotels as a place for } \\
\text { prostitutes. }\end{array}$ & $\begin{array}{l}\text { - Reforming the sector and galvanising local support towards changing the } \\
\text { perception of the industry. } \\
\text { - Adapting to changing competitive environment. } \\
\text { - Hotels hosting community and charity events to expose people to their } \\
\text { activities and services }\end{array}$ \\
\hline
\end{tabular}




\section{Table 3: Capacity-building activities in the hotel industry in Ghana}

\begin{tabular}{|c|c|}
\hline Dimensions & Nature of activities \\
\hline Staff capacity building & $\begin{array}{l}\text { - The government organised workshops on health and safety, leadership skills and hotel management. } \\
\text { - Training and development schemes were developed and carried out by industry bodies alongside } \\
\text { government agencies. } \\
\text { - New approach to promptly update information on quality and service standards. } \\
\text { - Regional education and training sources to assist small-business owners. } \\
\text { - Utilising links with ECOWAS and other regional bodies/hotels to help enhance the capacity of skilled and } \\
\text { unskilled personnel in the industry. }\end{array}$ \\
\hline $\begin{array}{l}\text { Facilities and services } \\
\text { capacity building }\end{array}$ & $\begin{array}{l}\text { - Revitalising and equipping hotels through industry training and instituting compliance and inspections } \\
\text { regime which adhere to international standards. } \\
\text { - Designing and implementing robust waste management system. } \\
\text { - Introducing new service-quality standards for small and medium-sized hotels. } \\
\text { - Introduction of new technologies and encouraging small hotels to develop an online presence. } \\
\text { - Upgrading of facilities including rooms and provision of more sports and entertainment TV channels. } \\
\text { - The government focused on establishing classification of formal and informal tourism establishments. } \\
\text { - Embarking on strong marketing campaigns of tourist sites, local attractions and local hotels both locally } \\
\text { and abroad. }\end{array}$ \\
\hline
\end{tabular}

Sources: Fieldwork; NDPC, 2005; GNA, 2005. 